Журнал«Герспективитаінноваціїнаукиљ

(Серія«Гедагогіка», Серія«Гцихологія», Серія«Медицинв»

№2(7) 2022

УДК 336.741.242

https://doi.org/10.52058/2786-4952-2022-2(7)-392-404

Крамаренко Ірина Сергіївна кандидат педагогічних наук, начальник відділу наукового дослідження та впровадження засобів навчання в освітній простір, Державна наукова установа «Інститут модернізації змісту освіти», вул. Василя Липківського, 36, м. Київ, 03035, тел.: (093) 280-46-47, https://orcid.org/0000-0002-4692-2778

Фонарюк Олена Василівна кандидат педагогічних наук, доцент кафедри алгебри та геометрії, Житомирський державний університет імені Івана Франка, вул. Велика Бердичівська, 40, м. Житомир, 10002, тел.: (097) 283-60-60, https://orcid.org/0000-0001-7879-5884

Зацерківна Марина Олексіївна кандидат наук з соціальних комунікацій, старший викладач кафедри інформаційних технологій, Київський національний університет культури і мистецтв, вул. Свгена Коновальця, 36, м. Київ, 01601, тел.: (099) 529-00-39, https://orcid.org/0000-0003-0745-7671

\title{
ЦИФРОВІЗАЦІЯ ОСВІТИ - НОВІ ВИКЛИКИ ТА ПЕРСПЕКТИВИ РОЗВИТКУ
}

Анотація. Світова криза, спричинена пандемією Covid-19, та актуальні цифрові трансформації надали значний поштовх для змін в організації функціонування більшості сфер життєдіяльності людства. Впливу піддалась і система освіти, яка сьогодні характеризується оновленням механізмів та інструментів організації освітніх процесів, а також поширенням практики застосування цифрових, інформаційно-комунікаційних технологій задля забезпечення безперервності комунікації між учасниками системи дистанційного навчання. Визначаючи перспективи розвитку освіти в еру динамізації цифрових трансформацій варто зауважити, що існують як можливості, які здатні вплинути на якісні складові освітнього процесу та забезпечити оптимізацію структури навчання у ЗВО, так і виклики, що стоять перед учасниками освітніх систем і вимагають актуалізації процесів розвитку нових особистісних компетенцій та навичок використання прогресивних технологій, які дедалі займають все більшу частку у структурі організації навчання студентів. Відтак, сьогоденні тенденції значно змінюють механізми та форми здобуття знань, а тому вимагають перманентних досліджень задля виокремлення характерних закономірностей та перспектив розвитку освіти в умовах цифрових трансформацій. Наукова стаття являє собою оригінальне дослідження феномену цифровізації як глобального явища, що впливає на якість, форми організації та перспективи розвитку освіти, а також створює 
виклики для учасників навчальних процесів. Дослідження проблематики здійснювалось завдяки застосуванню методів порівняння, абстракції, аналізу та узагальнення, а також методів графічного і табличного моделювання. В ході дослідження було детерміновано сутність та риси цифровізації, узагальнено значення цифрових трансформацій в контексті їх впливу на структуру організації освіти та процеси здобуття знань. Науковцями досліджено цифровізацію у двох вимірах: як явища, яке позитивно вливає на функціонування системи освіти, підкреслює перспективність розвитку неформальних форм навчання у порівнянні із традиційними, а також як явища, яке вносить безпрецедентні зміни у структуру навчальних процесів, а тому зумовлює виклики для учасників системи освіти, значна частка яких не була готова до кардинальної трансформації форм навчання.

Ключові слова: цифрові трансформації, феномен цифровізації, система освіти, розвиток, інформатизація, інформаційно-комунікаційні технології, освітнє середовище.

Kramarenko Iryna Sergiyivna Candidate of Pedagogic Sciences, head of the department of scientific research and implementation of teaching aids in the educational space, State Scientific Institution "Institute of education content modernization", Vasyl Lypkivsky St., 36, Kyiv, 03035, tel.: (093) 280-46-47, https://orcid.org/0000-0002-4692-2778

Fonariuk Olena Vasylivna Candidate of Pedagogical Sciences, Associate Professor at the Department of Algebra and Geometry, Zhytomyr Ivan Franko State University, Velyka Berdychivska St., 40, Zhytomyr, 10002, tel.: (097) 283-60-60, https://orcid.org/0000-0001-7879-5884

Zatserkivna Maryna Oleksiyivna, Candidate of Sciences in Social Communications, Senior Lecturer of the Department of Information Technology, Kyiv National University of Culture and Arts, Eugene Konovalets, St., 36, Kyiv, 01601, tel.: (099) 529-00-39, https://orcid.org/0000-0003-0745-7671

\section{DIGITALIZATION OF EDUCATION - NEW CHALLENGES AND PROSPECTS OF DEVELOPMENT}

Abstract. The current global crisis, which began by the Covid-19 pandemic, and digital transformations have unleashed another wave of reactions entailing reconsideration of the conventional wisdom and procedure of functioning of different spheres of life. Such transformations have had a manifest impact on the education system. Today the education system is characterized by amendment of the principles, mechanism and tools for organizing training, as well as the spread of the practice using of digital, information and communication technologies in the process of communication between the distance education system participants. At the time of the 
digital transformations there are opportunities for positive developments of education system, improve the quality of teaching and learning as well as modernization of the structure of learning. But the difficulties appear too; it is a characteristic feature of the process of reformation. The challenges of digitalization related to the need of formation of modern digital infrastructure as well as development of skills of using information and communication technologies and improve of digital literacy level distance education system participants. So these aspects acknowledge the relevance of problematic. The article is devoted to the analysis of the digitalization phenomenon as a global trend, which has impact on quality of education, forms and structure of learning process as well ae the prospects of development education and challenges faced by distance education system participants. Comparison, methods of abstraction, analysis and generalization, graphic and tabular modeling are the research methods which were used in the article.

In this science paper the essence of digitalization of education, the feature of the phenomenon are determined; the role of the digital transformations in the context of their influence on structure of learning process and functioning of education system are analyzed. The digitalization was researched by authors in two ways: first of all as a phenomenon, which has a positive impact on the development of non-formal form of education and confirm the potential of digital learning; secondly as a phenomenon that alters the traditional forms of education, which imply new difficulties for distance education system participants.

Keywords: digital transformations, digitalization phenomenon, education system, development, informatization, information and communication technologies, educational environment.

Постановка проблеми. Цифровізація, як соціокультурний феномен сьогодення, стала одною із причин розвитку більшості сфер життєдіяльності суспільства, в тому числі і освіти. Якість і досконалість форм, механізмів, інструментів навчання визначають рівень професійної підготовки, майстерності і компетентності майбутнього фахівця. Дедалі вимоги до працівників мають тенденції до підвищення, а очікування від результатів їх роботи динамічно ростуть. Відповідно, система освіти має бути одною із найбільш прогресивних галузей діяльності у державі, яка буде здатна забезпечити процеси підготовки кваліфікованих фахівців із високим рівнем професіоналізму та сукупністю позитивних особистісних якостей. Цифрові трансформації та оновлення форм організації навчального процесу $\epsilon$ особливо актуальними в контексті вдосконалення структури та принципів функціонування освіти.

Важливим фактором розвитку $є$ наявність як позитивних тенденцій, що підкреслюють перспективність роботи оновленої системи, так і негативних, які формують сукупність викликів для учасників навчальних процесів, змінюють їх традиції та звичні форми організації навчання, вимагають перманентного саморозвитку та роботи над формуванням нових компетенцій, зокрема цифрової грамотності i майстерності використання інформаційно-комунікаційних, 
цифрових технологій як обов'язкових елементів траєкторії здобуття нових знань і навичок. Дедалі цифрові трансформації лише більше змінюють буденність та принципи організації навчання, а тому доцільною $є$ робота над вивченням механізмів функціонування оновленої системи освіти, яка вже сьогодні являє собою симбіоз традиційних та прогресивних неформальних методик навчання майбутніх фахівців.

Аналіз останніх досліджень і публікацій. Тенденції цифровізації освіти, а також перспективи поширення новітніх IKT та цифрових інструментів забезпечення організації навчального процесу досліджено у багатьох працях сучасних науковців. Значний вклад у дослідження проблематики зробили В. Биков [1-2], В. Зайчук, О. Овчарук [2], А. Гуржій, В. Лапінський [3], Л. Карташова [3-5], І. Пліш, І. Іванюк [6], С. Ніколаєнко та ін. Так, В. Биков досліджує різні аспекти цифровізації освіти та розвитку інноваційних технологій в умовах цифрових трансформацій. Науковцем визначено, що цифровізація, як глобальне явище, є об'єктивним фактором використання цифрових та інноваційних технологій в освіті; в свою чергу, актуалізація цифрових трансформацій пов'язана із розвитком штучного інтелекту, робототехніки, мобільно-орієнтованих методів навчання, поширенням технологій віртуалізації інформації, формуванням практики використання електронних інформаційних баз i систем, а також становленням мереж постачальників ІКТ-послуг [1, с. 192]. Окрім того, В. Биков, В. Зайчук, А. Гуржій та ін. досліджують готовність педагогів до цифрових трансформацій. Науковцями було визначено, що важливим фактором підвищення прихильності викладачів до змін у традиційному устрої навчання, а також подолання такої проблеми, як небажання педагогів запроваджувати цифрове дистанційне навчання, $\epsilon$ робота над підвищенням рівня їх цифрової грамотності i компетентності, а також забезпеченням гідних умов для безперервного професійного розвитку [2, с. 8]. А. Гуржій, Л. Карташова та В. Лапінський аналізують цифровізацію освіти в контексті зміни суспільного устрою та впливу цих процесів на організацію навчання. Визначено характерну ознаку сьогодення - перехід суспільства від постіндустріального до інформаційного. Науковці стверджують, що за таких умов проникнення цифрових технологій в систему освіти $€$ неминучим, оскільки цифрові технології стають потужною продуктивною силою суспільства. Науковці зазначають, що «людство вступило в новий тип цивілізації - інноваційний. Його характерною ознакою $\epsilon$ прискорена зміна знань, технологій, інформатизація життєдіяльності» [3, с. 10]. Окрім того, Л. Карташова та Т.Сорочан висвітлюють нові погляди на організацію навчання в умовах переходу від традиційної системи управління навчанням (Learning Management Systems - LMS) до сучасної концепції цифрового навчального середовища наступного покоління (Next Generation Digital Learning Environment - NGDLE) як екосистеми, побудованої на засадах використання цифрових інструментів підтримки навчання учасників освітнього процесу. Науковці отримали висновок, що в умовах цифровізації кожен 
окремий заклад освіти стає «динамічним цифровим ресурсом, який укріплюється взаємозв'язком контенту, систем, засобів, включенням штучного інтелекту та доповненої й віртуальної реальності» [4, с. 21]. Л. Карташова та I. Пліш аналізують тенденції цифрового суспільства, цифрові тренди та виклики для освіти України, порядок гармонізації освітніх тенденцій з європейськими та світовими науковими ініціативами [5].

Виклики, що стоять перед суб'єктами системи освіти узагальнено у працях В. Бикова, О. Пінчук та О. Спіріна [7]. Виклики дистанційного навчання в умовах актуалізації цифрових трансформацій під тиском пандемії Covid-19 досліджує І. Іванюк [6]. В. Биков, О. Пінчук та О. Спірін визначили фактори, які зумовлюють загрозу розвитку цифрових технологій навчання студентів та значно ускладнюють процеси організації навчального процесу у 3ВО, а саме: виклики, пов'язані із відсутністю ефективної стратегії і тактики практичного впровадження єдиного освітнього інформаційного простору, виклики, пов’язані iз низькою якістю інфраструктурного забезпечення цифрового навчання, виклики, пов'язані із нагальною потребою у підвищенні рівня інформаційнокомунікаційно-технологічних (IКТ-компетентностей) та цифрових компетентностей, необхідних для використання учасниками навчального процесу цифрових технологій, а також виклики, зумовлені відсутністю регуляторного механізму та цілісної політичної стратегії застосування IКТ та цифрових інструментів в освіті [7, с. 28-30]. І. Іванюк визначила, що руйнівний вплив на процеси становлення неформальної цифрової освіти в Україні мають такі фактори, як недостатнє матеріально-технічне забезпечення навчання, брак часу через збільшення навантаження для викладачів, низький рівень самоорганізованості та мотивації здобувачів знань, загальне зниження якості освітніх послуг в умовах дистанціювання тощо [6, с. 3].

Виділення не вирішених раніше частин загальної проблеми. В ході аналізу праць сучасних науковців було визначено, що більшість із робіт присвячена детермінуванню цифровізації освіти як сучасному феномену, а актуалізація цифрових трансформацій визначається як ціль в умовах реформування системи освіти та збереження Україною євроінтеграційного вектору розвитку. Проте, на наш погляд, в умовах недостатньо високої ефективності освітніх послуг цифровізацію доцільно використовувати як інструмент управління якістю освіти. Відповідно, важливим аспектом $\epsilon$ обгрунтування цифровізації в контексті їі перспективності як інструменту організації навчального процесу на засадах прогресивних IКT та цифрових технологій, що і зумовлює необхідність у проведенні подальших досліджень проблематики.

Мета - проведення оригінального дослідження сутності та тенденцій цифровізації як глобального явища, що впливає на якість, форми і інструменти організації, перспективи розвитку освіти, а також створює виклики для учасників навчальних процесів в умовах динамічних змін. Для досягнення поставленої мети було сформовано та вирішено такі завдання, як: 
-проаналізувати сутність та роль цифровізації як явища, яке значно впливає на організацію функціонування системи освіти у державі;

-дослідити результати цифрових трансформацій в Україні на сучасному етапі розвитку, узагальнити виклики, що стоять перед учасниками навчальних процесів в умовах діджиталізації;

-охарактеризувати фактори, які підкреслюють перспективність розвитку цифровізованої системи освіти в Україні.

Виклад основного матеріалу. Цифровізація освіти $є$ сьогоденним трендом, який отримав стимули для розвитку у зв’язку із інтенсифікацією цифрових трансформацій, поширенням цифрових та інформаційнокомунікаційних технологій (далі - IKT) у навчанні школярів і студентів, а також вибором Україною інноваційно-орієнтованого вектору розвитку системи освіти (що цілком виправдано в умовах глобалізаційних зрушень та інтеграціiі). Цифровізація може бути дослідженою у різних вимірах - як стратегічна ціль, як результат динамізації розвитку технологій та зростання темпів інноваційної активності, як соціокультурний феномен, як інструмент забезпечення організації функціонування системи освіти в умовах дистанціювання та прагнення учасників освітніх процесів зберегти гнучкість і автономність навчання. Досліджуючи цифровізацію як стратегічну ціль варто визнати, що іiі досягнення передбачає реалізацію трьох завдань - факторів успіху побудови цифрової системи освіти [8]:

1. Стимулювання процесів проникнення технологій у програми навчання.

2. Поглинання цифрових технологій системою освіти та адаптація традиційних методик навчання до вимог високотехнологічного, постіндустріального суспільства, дотримуючись стратегії збалансованого використання традиційних та неформальних інструментів забезпечення освітніх процесів.

3. Інтенсифікація практичного використання технологій в освіті.

Як соціокультурний феномен цифровізація $є$ перспективним механізмом оновлення й розвитку сучасних закладів освіти. Сутність феномену полягає у кардинальній зміні форм навчання у напрямку формування їх нової якості. Феномен діджиталізації передусім має важливе значення для громадян, які безпосередньо залучені до взаємодії із прогресивними цифровими технологіями. В ході цифрових трансформацій відбулись зміни в організації системи освіти, які отримали своє відображення в оновленні форм навчання та принципів побудови навчального процесу. Визначальними факторами, які детермінують діджиталізацію як соціокультурний феномен, $\epsilon$ відсутність умовних географічних бар’єрів для поширення цифрових технологій, глобальна доступність інформації і необмеженість їі обсягу. Ці аспекти свідчать про те, що цифрові трансформації стали невід'ємною частиною стратегії реформування системи освіти та вже сьогодні відіграють важливу роль у побудові навчальних процесів. 
Журнал«Герспективитаінноваціїнаукиљ

(Серія«Гедагогіка», Серія«ГТихологія», Серія«Медицина»

№2(7) 2022

Проте, в контексті оптимізації порядку функціонування системи освіти цифровізацію доцільно детермінувати як прогресивний інструмент досягнення високого рівня ефективності навчання, який підкреслює перспективність неформальних форм навчання, побудованих на засадах технологій і інновацій, а не лише традиційних форм опрацювання інформації (зокрема, в рамках проведення академічних занять). Таким чином, цифровізація освіти - це:

- $\quad$ по-перше, прогресивний інструмент впливу на організацію навчання та корегування ефективності освітніх процесів у державі;

- по-друге, специфічний метод стимулювання розвитку системи освіти через побудову відкритого інформаційного суспільства.

Освіта, як одна із пріоритетних сфер життєдіяльності громадян, потребує реформацій в частині:

-підвищення результативності і продуктивності функціонування;

-забезпечення сталого зростання та стабільної роботи в умовах обмеження соціальної взаємодії;

-поліпшення методології та умов підготовки майбутніх професіоналів;

-загального симулювання росту якості послуг, які пропонує національна система освіти.

Відповідно, цифровізація є мультикомпонентним інструментом, який надає усі необхідні засоби, механізми та технології підтримки безперервного функціонування галузі, незважаючи на існування сукупності внутрішніх i зовнішніх загроз, спричинених пандемією Covid-19, підвищенням вимог до професійних якостей i компетенцій майбутніх фахівців, а також високою конкуренцією як на ринку освітніх послуг, так і на ринку праці.

На наш погляд, основними викликами сьогодення для учасників освітніх процесів $\epsilon$ низька забезпеченість системи цифровою інфраструктурою, а також відсутність належного рівня цифрових компетенцій тих учасників, які отримують освіту (студентів i школярів), а також тих, які зобов'язані безпосередньо організувати навчальний процес (викладачів, вчителів i вихователів).

Досліджуючи рівень розвитку цифрової інфраструктури доцільним $є$ аналіз світових рейтингів, які відображають готовність вітчизняної системи освіти до активізації цифрових трансформацій, а саме (табл. 1):

1. ІІ Індекс мережевої готовності (Networked Readiness Index - NRI) розроблений Всесвітнім економічним форумом (далі - WEF), Світовим банком (далі - WB) і Міжнародною школою бізнесу INSEAD Показник визначає рівень розвитку ІКТ у країнах світу. Структура індексу включає 4 субіндекси, а саме:

-наявність умов для розвитку ІКТ, які визначаються ефективність політичного i регуляторного середовища, зокрема законодавчою базою застосування IКT у різних сферах життєдіяльності, а також рівнем сприятливості бізнес-середовища та активністю розвитку інноваційної діяльності у державі; 
-готовність до розвитку ІКТ, який передбачає врахування стану інфраструктури, зокрема організацію виробництва електроенергії, коефіцієнт покриття мобільної мережі, міжнародну пропускну здатність Інтернету, а також рівень безпечності серверів Інтернету. Важливу роль при оцінці відведено i рівню доступності технологій, а також рівню готовності суспільства до застосування технологій чи, навпаки, існуванню особистісних бар'єрів i упереджень щодо їх використання у життєдіяльності;

-використання IКТ урядом, бізнесом і суспільством;

-вплив ІКТ на розвиток країни, який визначається шляхом детермінування економічних (вплив IКT на бізнес-моделі, заявки на патент РСТ IКT, вплив технологій на нові організаційні моделі, частка робочої сили, зайнятої в наукоємних заходах) та соціальних (вплив IКТ на доступ до основних послуг, доступ до Інтернету в закладах освіти, використання IКТ та ефективність уряду, Індекс електронної участі) ефектів.

2. Індекс розвитку інформаційно-комунікаційних технологій (ICT Development Index - IDI) - розраховується Міжнародним союзом електрозв’язку (далі - MCE). Структура індексу включає 3 субіндекси, а саме:

-інфраструктура IКT та показники доступу до ऑiі використання, який включає дослідження таких даних, як відсоток суб'єктів економічної системи держави 3 комп'ютерами та відсоток суб'єктів 3 доступом до Інтернету, пропускна здатність Інтернету (Біт/с) для кожного користувача, відсоток населення, яке охоплене мобільними мережами 3G, LTE/WiMax, фіксовані широкосмугові підписки на швидкісний Інтернет (256 Кбіт/с до 2 Мбіт/с, 2-10 Мбіт/с, 10 Мбіт/с і більше (\% від загальної кількості);

-показники використання IКТ, в рамках якого аналізується відсоток осіб, які користуються Інтернетом, активні підписки на мобільні широкосмугові канали (на 100 жителів), підписки на мобільний та фіксований широкосмуговий Інтернет-трафік, відсоток власників мобільного телефону;

-показники розвитку навичок використання IКT, а саме середні роки навчання, коефіцієнт середньої валової участі (\%), третинний рівень валового набору (\%), відсоток осіб у державі з навичками IКT.

Таблиия 1

Рівень розвитку цифрової інфраструктури в Україні в контексті дослідження викликів для держави в умовах актуалізації цифрових трансформацій

\begin{tabular}{|c|c|}
\hline $\begin{array}{l}\text { Назва рейтингу, позиція Украӥни та } \\
\text { стратегічні оріснтири держави }\end{array}$ & $\begin{array}{l}\text { Значення для розвитку системи } \\
\text { освіти в контексті циффровізації }\end{array}$ \\
\hline $\begin{array}{l}\text { 1. Індекс мережевої готовності - станом } \\
\text { на } 2021 \text { рік Україна займала } 53 \text { місце зі 134: } \\
\text {-оцінка за вектором «Середовище для } \\
\text { розвитку ІКТ»-49,2; } \\
\text {-оцінка за вектором «Готовність до } \\
\text { розвитку ІКТ»-54,3; }\end{array}$ & $\begin{array}{l}\text { Визначає готовність учасників } \\
\text { навчальних процесів до використання } \\
\text { новітніх інформаційно-комунікаційних та } \\
\text { цифрових технологій у освітній та } \\
\text { професійній діяльності; відображає рівень } \\
\text { цифрової грамотності та компетентності } \\
\text { суспільства. }\end{array}$ \\
\hline
\end{tabular}


-оцінка за вектором «Використання IКТ»

-оцінка за вектором «Вплив IКТ» - 60,4.

2. Стратегічний орієнтир для України не нижче 40 місця.

3. Лідери рейтингу станом на 2021 рік: Нідерланди, Швеція, Данія, США та Фінляндія.

1. Індекс розвитку IKT (ICT Development Index - IDI) - станом на 2017 рік Україна займала 79 місце.

2. Стратегічний орієнтир для України не нижче 50 місця.

Забезпечує процеси моніторингу розвитку IT, вимірювання прогресу у розвитку ІКТ, а також визначення цифрового розриву між державами світу; показник визначає обсяги потенціалу для розвитку ІКТ і перспективи цифровізації в контексті аналізу можливостей підвищення зростання та розвитку держави.

Джерело: складено авторами за даними [9], [10].

Аналіз рейтингових позицій України за міжнародними рейтинговими індексами свідчить про неоднозначність позицій країни у світовому цифровому середовищі, зумовлену низькою інфраструктурною забезпеченістю. В контексті детермінування рівня розвитку національного цифрового середовища було визначено, що існує значний цифровий розрив України з країнами-сусідами, а це значно ускладнює розвиток цифрових трансформацій в освіті та створює виклики для учасників системи в контексті відсутності ефективного середовища для організації процесів неформального навчання.

Наступним викликом для учасників навчання $\epsilon$ недостатньо висока цифрова грамотність, яка перешкоджає використанню ними усіх переваг цифрового середовища через відсутність навичок практичного застосування деяких із цифрових інструментів. Рівень цифрової грамотності українців $\epsilon$ актуальним питанням, яке вимагає перманентних досліджень, а тому в рамках діяльності Міністерства цифрової трансформації України проводяться щорічні загальнонаціональні опитування, які відображають стан готовності населення до цифровізації. Дослідження здійснюється за такими напрямами:

-аналіз інформаційних навичок, який відображає рівень готовності громадян до визначення, знаходження, витягування, зберігання, впорядковування та аналізу цифрову інформацію, відповідно до ії актуальності та призначення;

-аналіз комунікаційних навичок, який відображає готовність громадян до спілкування в цифрових середовищах, обміну ресурсами за допомогою онлайнінструментів, зв'язку 3 іншими та співпраці за допомогою цифрових інструментів, взаємодії та прийняття участі у спільнотах та мережах;

-аналіз навичок вирішення життєвих проблем, який відображає готовність до прийняття обгрунтованих рішень щодо того, які є найбільш підходящими цифрові інструменти відповідно до мети або як потрібно вирішувати концептуальні проблеми за допомогою цифрових засобів; 
-аналіз навичок створення цифрового контенту, який відображає готовність до створення та редагування нового вмісту (від обробки тексту до зображень та відео), інтегрування та переробки попередніх знань у нові форми;

-аналіз навичок розв'язання проблем у цифровому середовищі та навчання впродовж життя, який відображає готовність громадян до вирішення проблем, використовуючи цифрові технології, а також до використання відкритих цифрових освітніх ресурсів для професійного розвитку та особистісного саморозвитку без часових і просторових обмежень протягом життя.

За результатами опитувань всіх респондентів, відповідно до методології дослідження, згруповують у три групи: no skills - особи, які не застосовували жодну 3 цифрових навичок за останні 3 місяці, basic skills - особи, які застосовували один навик за останні 3 місяці, above basic skills - особи, які застосовували більше одного навику за останні 3 місяці (Рис. 1).

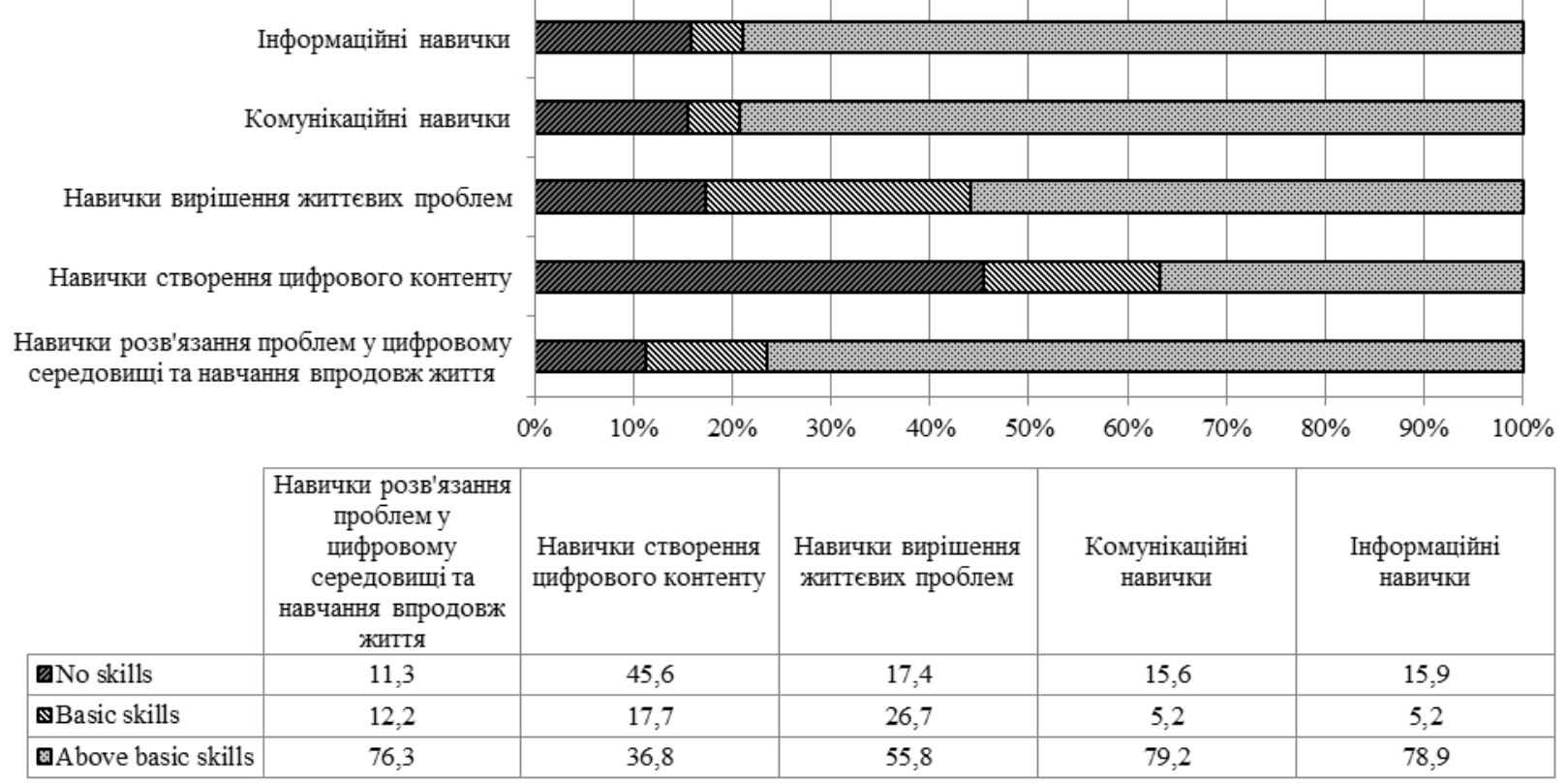

Рис. 1. Цифрова грамотність населення Украӥни за результатами 2021 року Джерело: складено авторами за даними [11].

Дані рис. 1 свідчать про те, що велика частка населення України (а це майже $20 \%$ респондентів) не мають навичок практичного застосування IКТ у повсякденному житті або ж їх розвиток знаходиться на початкових етапах, чого не достатньо для організації високотехнологічного, ефективного навчального процесу. Відповідно, майже $25 \%$ респондентів не готові до переведення освітніх процесів у цифровий простір, а також з обережністю ставляться до концепції цифрового навчання впродовж життя, оскільки не мають відповідних компетенцій.

Відповідно до аналізу даних щодо стану розвитку цифрової інфраструктури та рівня цифрової грамотності населення України можна говорити про існування значних труднощів для сьогоденної системи освіти. Інфраструктура, 
як базове забезпечення процесів навчання, вимагає розвитку і вдосконалення, стан готовності суспільства до цифровізації, як чинник стимулювання цифрових трансформацій в освіті, вимагає опрацювання. Першочерговим етапом на шляху підвищення готовності здобувачів знань до динамізації цифрових змін $\epsilon$ донесення думки про перспективність цифрової, дистанційної або змішаної форм навчання, гнучкість та їх автономність в порівнянні із традиційними формами. Факторами, які підтверджують пріоритетність цифрового освітнього середовища над традиційним, $є$ такі:

1. Вища доступність до освітніх послуг, а також послуг, необхідних для життєдіяльності громадян. Елементи екосистеми цифрової освіти сприяють формуванню навичок практичного застосування ІКТ у буденному житті, що в перспективі спрощує порядок застосування громадянами цифрових сервісів;

2. Стратегічність цифрової освіти, яка передбачає використання цифровізації як інструменту формування лояльного сприйняття громадянами актуалізації процесів цифрових трансформацій у різних сферах життєдіяльності, а також швидкої адаптації до прогресивних смарт-рішень;

3. Методологічність цифрової освіти, що передбачає виклад та поширення матеріалу, обрання таких методів i форм навчання, які $\epsilon$ інформативними, але зрозумілими для відповідної цільової аудиторії, а також змістовно відповідають вимогам концептуально-референтної Рамки цифрових компетентностей для громадян України.

4. Інноваційність цифровізації як інструменту організації навчання. Інновації і технології є орієнтирами на динамічні зміни в навколишньому світі та освітній діяльності, вини стимулюють розвиток різноманітних форм мислення, творчих здібностей, високих соціально-адаптаційних можливостей особистості. Вказаний фактор свідчить про відкритість цифровізованої системи освіти, іï здатність до передбачення і прогнозування на основі перманентної переоцінки цінностей, налаштованості на активні та конструктивні дії в швидко змінних ситуаціях.

Не зважаючи на існування певних складнощів в контексті динамізації розвитку високотехнологічної системи освіти в Україні, цифровізацію все ж таки варто визнати перспективним інструментом управління освітніми процесами. Цифровізація освіти надає можливості активізувати віртуальну мобільність студентів, проходити навчання і стажування в університетах інших країн. Цифровізація освітніх послуг робить Україну конкурентоздатною в контексті інтеграції національної системи освіти до єдиного європейського освітнього простору й розвитку академічної мобільності.

Висновки. В ході проведеного дослідження було визначено, що цифровізація освіти є інструментом, орієнтиром, а також глобальним явищем, яке впливає на якість, форми, методи організації, перспективи розвитку системи та концепцій навчання. Україна як держава, яка приймає активну участь у процесах інтеграції та піддається впливу з боку глобалізації, потребує реалізації трансформацій у сферах інфраструктурного забезпечення освітніх процесів. 
Враховуючи дані світових рейтингів готовність системи освіти до динамізації цифрових трансформацій $\epsilon$ низькою. Проте вагоме значення в контексті поширення практики цифровізації освіти займає і людський фактор. Зокрема, рівень цифрових навичок громадян має бути вищим задля забезпечення високої ефективності навчання.

Існування певних труднощів $є$ неминучим, оскільки держава перебуває на шляху реалізації змін, проте перспективність цих змін важко заперечити; цифровізація освіти $\epsilon$ інноваційним, високотехнологічним та стратегічноорієнтованим інструментом впливу на структуру та порядок організації навчання. Відповідно, подальша мета досліджень за обраним напрямом полягає у розробці методів вдосконалення цифрової інфраструктури у державі, а також стимулювання розвитку цифрових навичок, підвищення мотивації серед учасників навчальних процесів до надання пріоритетів збалансованому застосуванню традиційних та цифрових неформальних форм здобуття освіти.

\section{Jimepamypa:}

1. Биков В., Спірін О., Пінчук О. Проблеми та завдання сучасного етапу інформатизації освіти. Наукове забезпечення розвитку освіти в Україні: актуальні проблеми теорії і практики (до 25-річчя НАПН Украӥни) / за ред. С.В. Бартош. Київ: Видавничий дім «Сам», 2017. С. 191-198.

2. Bykov V. Y., Gurzhiy A. M., Zaichuk V. O., Kartashova L. A., Ivaniuk I. V., Ovcharuk O. V. Challenges and prospects of the use of digital learning instruments by teachers during the COVID-19 pandemic. Science and Education: зб. пр. XVI Міжнар. наук. конф.. Хмельницький: ХНУ, 2021. С. 3-8.

3. Гуржій А. М., Карташова Л. А., Лапінський В. В Інформатизація загальної середньої освіти в Україні. Modern achievements of science and educations: зб. пр. XIII Міжнар. наук. конф.. Хмельницький: ХНУ, 2018. С. 9-13.

4. Карташова Л., Сорочан Т. Цифрове навчальне середовище наступного покоління: як буде виглядати екосистема навчання після ери LMS. Інформаційні технології в професійній діяльності: зб. мат. XIV Всеукр. наук.-практ. конф.. Рівне: РВВ РДГУ. 2021. C. 19-22.

5. Карташова Л., Пліш І. Цифровий порядок денний розвитку освіти: спрямованість на формування цифрових компетентностей. Науковий вісник Мукачівського держсавного університету. Серія «Педагогіка та психологія». 2020. №1 (11). С. 135-139.

6. Іванюк I. В. Виклики дистанційного навчання в Україні в умовах карантину Covid-19. Вісник Начіональної академії педагогічних наук Украӥни. 2021. №3 (2). С. 1-4. DOI: https://doi.org/10.37472/2707-305X-2021-3-2-10-1

7. Биков В., Спірін О., Пінчук О. Сучасні завдання цифрової трансформації освіти. Вісник кафедри ЮНЕСКО «Неперервна професійна освіта ХХІ століття». 2020. №1. C. 27-36. DOI: https://doi.org/10.35387/ucj.1(1).2020.27-36

8. Цифрова адженда України - 2020. Available at: https://ucci.org.ua/uploads/files/ 58e78ee3c3922.pdf.

9. Network Readiness Index 2021. Shaping the Global Recovery: How digital technologies can make the post-Covid world more equal. Available at: https://networkreadinessindex.org/ (дата звернення 31.01.2022).

10. ICT Development Index. «IDI 2017 rank». Available at: https://www.itu.int/net4/ ITU\$D/idi/2017/ index.html. 
Журнал«Герспективита іновації наукиљ

(Серія«Гедагогіка», Серія«Гцихологія», Серія«Медицина»

№2(7) 2022

11. Цифрова грамотність населення України: звіт за результатами загальнонаціонального опитування / Міністерство цифрової трансформації України, 2021. Available at: https://osvita.diia.gov.ua/research.

\section{References:}

1. Bykov, V., Spirin, O., Pinchuk, O. (2017). Problemy ta zavdannja suchasnogo etapu informatyzacii' osvity [Problems and tasks of the modern stage of informatization of education]. Naukove zabezpechennja rozvytku osvity v Ukrai'ni: aktual'ni problemy teorii' i praktyky (do 25richchja NAPN Ukrai'ny) - Scientific support for the development of education in Ukraine: current issues of theory and practice (to the 25th anniversary of the NAPS of Ukraine). S.V. Bartosh (Ed.). (pp. 191-198). Kyi'v: Vydavnychyj dim «Sam» [in Ukrainian].

2. Bykov, V. Y., Gurzhiy, A. M., Zaichuk, V. O., Kartashova, L. A., Ivaniuk, I. V., Ovcharuk, O. V. (2021). Challenges and prospects of the use of digital learning instruments by teachers during the COVID-19 pandemic. Proceedings from Science and Education '21: XVI Mizhnarodna naukovo-praktychna konferentsiia - The Sixteenth International Scientific and Practical Conference. (pp. 3-8). Hmel'nyc'kyj: HNU [in Ukrainian].

3. Gurzhij, A. M., Kartashova, L. A., Lapins'kyj, V. V (2018). Informatyzacija zagal'noi' seredn'oi' osvity v Ukrai'ni [Informatization of general secondary education in Ukraine]. Proceedings from Modern achievements of science and educations '18: XIII Mizhnarodna naukovo-praktychna konferentsiia - The Thirteenth International Scientific and Practical Conference. (pp. 9-13). Hmel'nyc'kyj: HNU [in Ukrainian].

4. Kartashova, L., Sorochan, T. (2021). Cyfrove navchal'ne seredovyshhe nastupnogo pokolinnja: jak bude vygljadaty ekosystema navchannja pislja ery LMS [Digital learning environment of the next generation: what will look like the learning ecosystem after the LMS era]. Proceedings from Information technologies in professional activity '21: XIV Vseukrai'ns'ka naukovo-praktychna konferentsiia - The Fourteenth All-Ukrainian scientific-practical Conference. (pp. 19-22). Rivne: RVV RDGU [in Ukrainian].

5. Kartashova, L., Plish, I. (2020). Cyfrovyj porjadok dennyj rozvytku osvity: sprjamovanist' na formuvannja cyfrovyh kompetentnostej [Digital agenda of education development: focus on the formation of digital competencies]. Naukovyj visnyk Mukachivs'kogo derzhavnogo universytetu. Serija "Pedagogika ta psyhologija" - Scientific Bulletin of Mukachevo State University. Series "Pedagogy and Psychology", 1 (11), 135-139 [in Ukrainian].

6. Ivanjuk, I. V. (2021). Vyklyky dystancijnogo navchannja v Ukrai'ni v umovah karantynu Covid-19 [Challenges of distance learning in Ukraine under quarantine Covid-19]. Visnyk Nacional'noi' akademii' pedagogichnyh nauk Ukrai'ny - Bulletin of the National Academy of Pedagogical Sciences of Ukraine, 3 (2), 1-4. DOI: https://doi.org/10.37472/2707-305X-2021-3-2-10-1 [in Ukrainian].

7. Bykov, V., Spirin, O., \& Pinchuk, O. (2020). Suchasni zavdannja cyfrovoi' transformacii' osvity [Modern tasks of digital transformation of education]. Visnyk kafedry JuNESKO «Neperervna profesijna osvita HHI stolittja" - UNESCO Chair Journal "Lifelong Professional Education in the XXI Century”, 1, 27-36 [in Ukrainian].

8. Cyfrova adzhenda Ukrai'ny - 2020 [Digital Agenda of Ukraine - 2020], available at: https://ucci.org.ua/uploads/files/58e78ee3c3922.pdf (Accessed 31 January 2022) [in Ukrainian].

9. Network Readiness Index 2021. Shaping the Global Recovery: How digital technologies can make the post-Covid world more equal, available at: https://networkreadinessindex.org.

10. ICT Development Index. "IDI 2017 rank", available at: https://www.itu.int/net4/ ITU\$D/idi/2017/ index.html.

11. The Ministry of Digital Transformation of Ukraine (2021). Cyfrova gramotnist' naselennja Ukrai'ny: zvit za rezul'tatamy zagal'nonacional'nogo opytuvannja [Digital literacy of the population of Ukraine: a report on the results of a national survey], available at: https://osvita.diia.gov.ua/research [in Ukrainian]. 